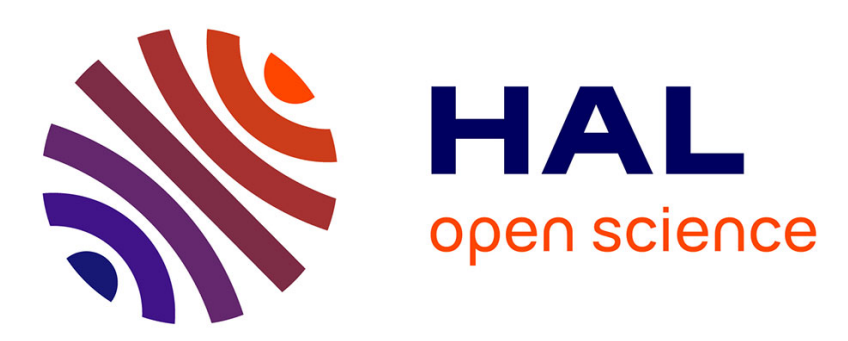

\title{
Softening trigerred by eclogitization, the first step toward exhumation during continental subduction
}

Laurent Jolivet, Hugues Raimbourg, Loïc Labrousse, Dov Avigad, Yves Leroy, Håkon Austrheim, Torgeir B. Andersen

\section{- To cite this version:}

Laurent Jolivet, Hugues Raimbourg, Loïc Labrousse, Dov Avigad, Yves Leroy, et al.. Softening trigerred by eclogitization, the first step toward exhumation during continental subduction. Earth and Planetary Science Letters, 2005, 237, pp.532-547. 10.1016/j.epsl.2005.06.047 . hal-00111447

\section{HAL Id: hal-00111447 \\ https://hal.science/hal-00111447}

Submitted on 18 Jan 2018

HAL is a multi-disciplinary open access archive for the deposit and dissemination of scientific research documents, whether they are published or not. The documents may come from teaching and research institutions in France or abroad, or from public or private research centers.
L'archive ouverte pluridisciplinaire HAL, est destinée au dépôt et à la diffusion de documents scientifiques de niveau recherche, publiés ou non, émanant des établissements d'enseignement et de recherche français ou étrangers, des laboratoires publics ou privés. 


\title{
Softening trigerred by eclogitization, the first step toward exhumation during continental subduction
}

\author{
Laurent Jolivet $^{\mathrm{a}, *}$, Hugues Raimbourg ${ }^{\mathrm{a}}$, Loïc Labrousse ${ }^{\mathrm{a}}$, Dov Avigad ${ }^{\mathrm{b}}$, Yves Leroy ${ }^{\mathrm{c}}$, \\ Håkon Austrheim ${ }^{\mathrm{d}}$, Torgeir B. Andersen ${ }^{\mathrm{d}}$
}

${ }^{\mathrm{a}}$ Laboratoire de Tectonique, UMR 7072, Université Pierre et Marie Curie, T46-0 E2, case 129, 4 place Jussieu, 75252 Paris cedex 05, France

${ }^{\mathrm{b}}$ Institute of Earth Sciences, Hebrew University of Jerusalem, Jerusalem, Israel

${ }^{\mathrm{c}}$ Laboratoire de Mécanique des Solides, Ecole Polytechnique, Palaiseau, France

${ }^{\mathrm{d}}$ Institutt for Geofag, Universitet I Oslo, Postboks 1047, Blindern, N-0316 Oslo, Norway

Direct observation of peak pressure deformation in exhumed subduction channels is difficult because little evidence of this deformation survives later syn-exhumation deformation. Most ultrahigh-pressure parageneses are found in continental derived metamorphic rocks making continental subduction the best context to observe peak pressure deformation. Whereas many studies have enlightened the main driving parameters of exhumation such as buoyancy forces, low viscosity in the subduction channel, overburden removal by erosion and normal faulting, a basic question is seldom considered: why is a tectonic unit disconnected from the descending lithosphere and why does it start its way towards the surface? This event, seminal to exhumation processes, must involve some deformation and decoupling of the exhumed slice from the descending slab at peak pressure conditions or close to it. Our field observations in the Bergen arc show that Caledonian eclogitization and later amphibolitization of a granulitic terrane was achieved with a consistent component of simple shear compatible with the sense of the Caledonian subduction. Thus, the sequence of deformation preserved in the Bergen Arc documents the decoupling of subducted crustal material from the descending slab at the onset of exhumation. This observation suggests that deformation in the subduction channel is largely controlled by kinematic boundary conditions, i.e. underthrusting of the subducting slab. In this context of simple shear, metamorphic reactions assisted by fracturating, fluid infiltration and ductile deformation lower the resistance of rocks and allow the localisation of shear zones and the decoupling of buoyant tectonic units from the subducting slab. These tectonic units can then be incorporated into the channel circulation and start their upward travel.

Keywords: Eclogite; exhumation; Bergen; Caledonides; Norway; softening; shear zones

\footnotetext{
* Corresponding author.

E-mail address: laurent.jolivet@lgs.jussieu.fr (L. Jolivet).
} 


\section{Introduction}

Subduction of continental or oceanic material leads to the formation of high-pressure or ultra-high-pressure metamorphic rocks [1-4]. Eclogites are typical metamorphic rocks in such environments. While driving them down in the subduction channel along with the subducting lithosphere is easy to conceptualize, their exhumation, usually fast, is much less easily understood.

Exhuming high-pressure metamorphic rocks during convergence from below mountain belts or from the depths of the subduction channel requires that buoyancy forces and/or forces related to shearing along the subduction plane overcome forces that keep these rocks attached to the descending lithosphere. Metamorphism plays an important role in changing the balance of forces [5]. Metamorphic recrystallisation during burial can lead to a significant density increase (up to $10 \%$ in the case of eclogitization of a mafic material [6]) and may prevent exhumation. But recrystallisation is rarely complete at large scale. The Western Gneiss Region and the Bergen Arc of western Norway for instance show one of the largest eclogitized piece of continental crust [5,7] exhumed during the Caledonian orogeny. This continental basement has been buried to large depths and only partly recrystallised into high-density eclogite-facies mineral associations. Its bulk density is thus not that of a fully recrystallised eclogite and eclogitization is not advanced enough to prevent exhumation. Eclogitization has other consequences than a density increase. Earlier studies of the Bergen arc have shown that recrystallisation in the eclogite facies is accompanied with a significant reduction in rocks strength [8] shown by a systematic localisation of shear zones where the host granulites have been transformed to eclogites. We explore in this paper the kinematics of syn-eclogite deformation in the Bergen arc which suggests that eclogitization is ultimately responsible for the separation of tectonic units from the descending lithosphere.

\section{About the importance of direct field observations}

The behaviour of rocks subducted in the deep parts of accretionnary complexes or subduction channels can be indirectly approached by the study of seismicity or directly observed on exhumed rocks. Intermediatedepth and deep earthquakes in subduction zones exhibit classical fault-related focal mechanisms showing that shear failure is responsible for the fast motion. Focal mechanisms indicate a majority of low-angle thrust faults together with normal faults in the upper plane of double- or triple-planed subduction zones [9]. Several mechanisms have been proposed to explain shear failure at such large depths: thermal control of the depth of the brittle-ductile transition [10], reactivation of fault planes created at shallow depth [11], metamorphic transformation-faulting [12]. The last mechanism is however unlikely for intermediate earthquakes for at such depth most reactions are not polymorphic and thus involve the slow mechanism of diffusion [13]. Dehydration embrittlement is considered a viable mechanism for producing earthquakes in oceanic subduction zones [13-16]. In double planed subduction zones the upper plane corresponds to dehydration of the crust and the lower plane to dehydration of serpentinite in the mantle [13]. Fluids produced by dehydration can then facilitate the transformation of the dry gabbros into eclogites $[14,17]$. Several of these mechanisms give a major role to local stress concentration due to dehydration or volume changes. The role played by shearing boundary conditions expected in the subduction channel being not clearly understood it is critical to make detailed observations of strained rocks in exhumed high-pressure metamorphic rocks. This is possible in mountain belts resulting from continental subduction.

Field studies, estimates of P-T-t paths as well as thermo-mechanical models have shown that exhumation (overburden removal) involves a combination of erosion and normal faulting and that the kinematics inside the subduction channel is driven by (a) buoyancy forces and (b) forces due to the channel geometry (corner flow) [18-23]. Thermal weakening of crustal material and the presence of rheologically weak phases such as migmatites or serpentinites tend to facilitate this circulation $[24,25]$. Unlike the P-T paths which normally are interpreted to record the evolution from the peak pressure to the surface, structures that can be used to infer a large-scale kinematics only show in most cases the late lower-pressure evolution. This situation is clearly illustrated by the Dora Maira massif in the Alps where most shear zones were formed in the blues- 


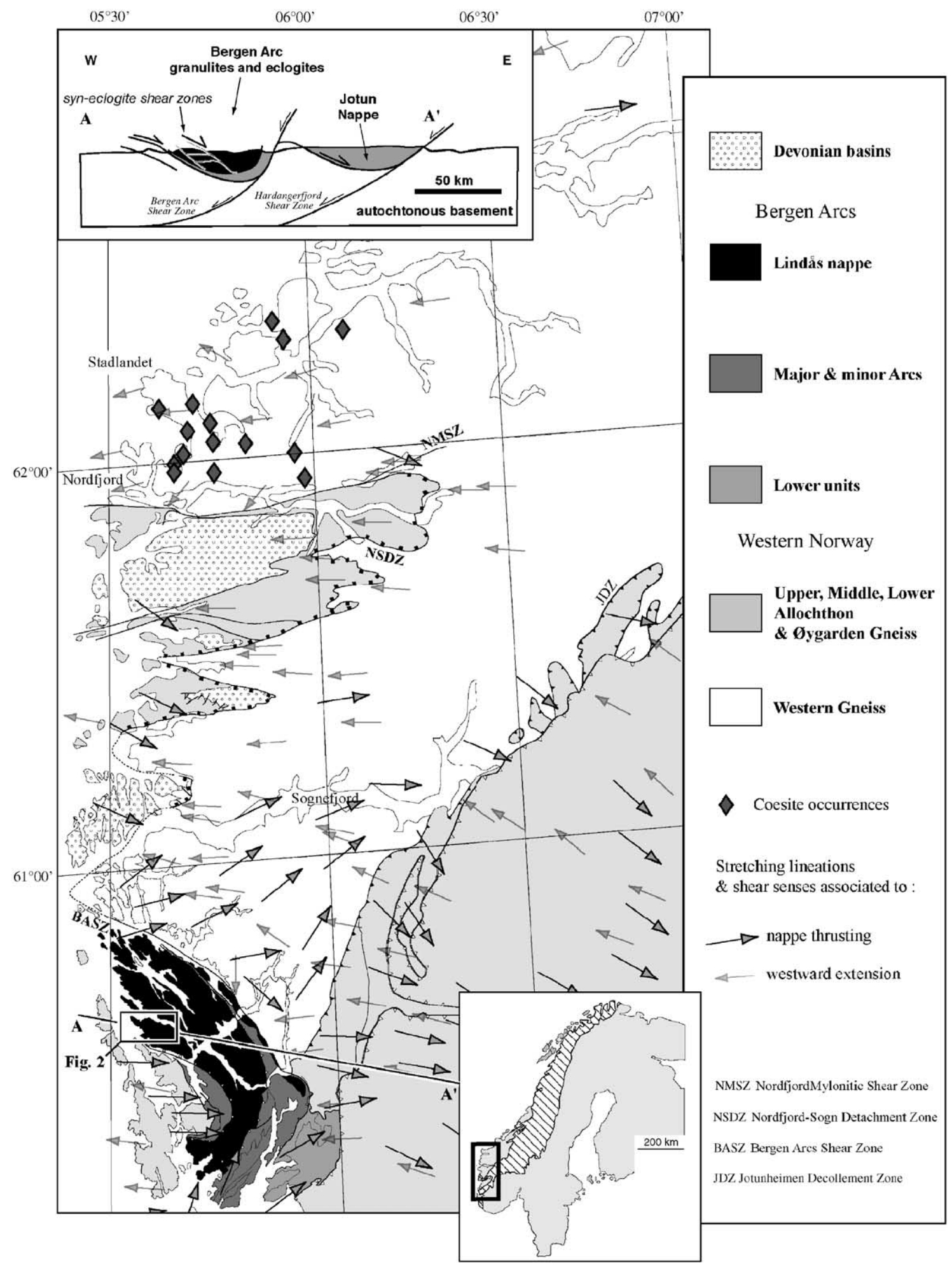


chist and greenschist facies, certainly not near the peak of pressure [26]. In the Norwegian Caledonides the ultra-high-pressure terrains north of the Hornelen Devonian basin $[2,27]$ were highly retrograded, partially molten and sheared during their way back to the surface $[25,28]$. The deformation pattern near the peak of pressure has been lost in most cases. It is thus difficult to answer fundamental questions such as (1) which deformation regime is active in the subduction channel and (2) why is a tectonic unit decoupled from the subducting lithosphere and integrated in the channel flow to start its travel back to the surface?

Answering these questions requires that the mechanical behaviour and the deformation style at or near the peak of pressure can be observed and, first of all, a kinematic pattern inferred on a significant scale.

Among the few examples where a coherent peak pressure (eclogite facies) deformation has been preserved the Caledonian Lindås Nappe of the Bergen Arc (Fig. 1) is certainly the most spectacular. Previous studies have documented the progressive eclogitization of the Precambrian granulites, and emphasised the role of deep-seated brittle fracturing and fluid migration $[6,29,30]$. Metamorphic transformation is heterogeneous and metastable granulites are preserved between fully transformed Caledonian eclogite facies shear zones that have a lower viscosity [31]. Our field observations show that eclogitization and subsequent amphibolitization were achieved with a consistent component of simple shear compatible with the sense of the Caledonian subduction.

\section{Geological setting}

The Scandinavian Caledonides represent the eastern part of the large lower Paleozoic orogen that encompasses western Scandinavian, most of the British Isles, East-Greenland, Spitbergen, and the eastern margin of North America [32]. The North Atlantic Caledonides developed between ca 500 and $400 \mathrm{Ma}$ from the closure of the Iapetus Ocean and continent-continent collision of Baltica-Avalonia and Laurentia [33-35]. The moun- tain belt (Fig. 1) was formed by the accretion of Baltic and outboard terranes towards the southeast and east. High-pressure and ultrahigh-pressure eclogite facies rocks dated at 415-400 Ma were described in the Western Gneiss Region below the Nordfjord Detachment Zone [25,27,28,36-38]. These eclogite facies rocks containing metamorphic coesite, majoritic garnets and diamonds were exhumed along isothermal P-T paths before and during the deposition of the continental Devonian basins $[25,37,39]$. A continuum of vertical shortening to top-to-the-west shear, opposite to the preceding crustal thickening, is recorded during exhumation from deep ductile deformation often associated to partial melting to brittle deformation along the detachment $[25,32,37,39]$.

Older eclogites (420 Ma) of the Bergen Arc nappes rest above the Western Gneiss region [40-42]. Precambrian granulitic anorthosites and mangerites, similar to the basement of the Western Gneiss region, make the core of the Lindås Nappe $[8,43]$. They show a progressive eclogitization associated with the formation of shear zones [6]. Eclogitization was followed by amphibolitization and final recrystallization in the greenschist facies during exhumation $[40,44,45]$. The basal contact of the Bergen arcs is originally a thrust that brought a piece of continental crust eclogitised some 420 Myrs ago above the Western Gneiss region that was eclogitised only 20 Myrs later (Fig. 1). This same contact was reactivated later as an extensional detachment during the exhumation of the Western Gneiss Region.

The western part of Holsnøy island was explored in details [5,6,29-31,46-49] (Fig. 2). One important result of these investigations is that deformation, fluid income and eclogitization were contemporaneous and that shear zones localized in the less resistant material, i.e. hydrated eclogites in this example, and that further deformation led to further fluid income and further recrysallization. Whether the fluid is mainly $\mathrm{H}_{2} \mathrm{O}[50]$, or contains other elements as well [48,51] is a disputed question, but in all cases $\mathrm{H}_{2} \mathrm{O}$ is predominant. Previous studies have emphasized the cooperation between fluid infiltration and metamorphic reactions to produce an increase of ductility (reac-

Fig. 1. Map of the Norwegian Caledonides and location of the Bergen arc [25,37,59,80-85]. Kinematic indicators show the direction and sense of nappe emplacement (large and dark arrows, top-to-the-east) and subsequent extension (small arrows, top-to-the-west) in the Western Gneiss Region and the Bergen Arc as well as the occurrence of ultra-high-pressure metamorphic rocks. A cross-section (AA') shows the position of the Bergen Arcs as thrusts sheets resting on top of the Western Gneiss (after [53]). 


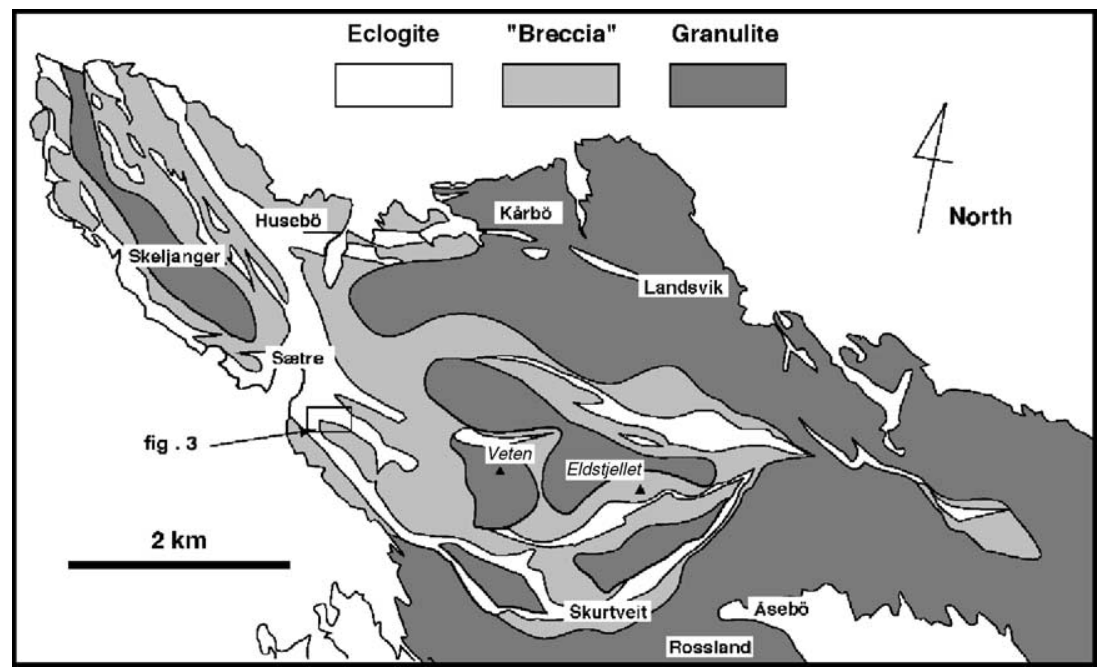

Fig. 2. Map of western Holsnøy after [47] showing the distribution of untransformed granulite and eclogite facies shear zones.

tion-softening) and enhance deformation that in turn can help both fluid infiltration and reactions in the Bergen Arcs and the Western Gneiss Region further north $[5,49,52]$. The now commonly accepted view of the deformation history is that (1) the Bergen Arcs granulites were brittlely fractured in the P-T conditions of the eclogite facies, (2) fluid infiltration and/or shearing caused eclogitization, and (3) that further deformation and/or fluid intrusion were localized in the eclogitic material, weaker than granulite, thus enhancing further recrystallization and so forth. Field relations thus show that eclogite is weaker than granulite although it may seem counter-intuitive to mention the weakness of eclogite that is usually preserved as resistant boudins in amphibolites or blueschists.

Eclogite form within a precambrian granulitic protolith $[43,53]$. P-T conditions deduced from the eclogite paragenesis $\left(650-750{ }^{\circ} \mathrm{C}\right.$ and $\left.15-17 \mathrm{Kbar}[8,47]\right)$ suggests a depth of around $50 \mathrm{~km}$. Later amphibolitization reworking the eclogite paragenesis during exhumation provides lower pressure and lower temperature conditions $\left(600-700{ }^{\circ} \mathrm{C}, 8-12 \mathrm{Kbar},[41,44]\right)$. Large-scale anastomosing shear zones that can be traced several kilometres along strike trend NW-SE and cut across the granulitic Precambrian foliation [47]. Within the shear zones the granulites are almost totally recrystallized into eclogites $(>80 \%)$. Microstructural studies [54] show that deformation proceeded within the sta- bility field of eclogite facies minerals. Outside the shear zones a gradation from complete transformation to pristine granulite is observed. Fractures in the granulites contain pseudotachylites that were formed at high pressure in the P-T conditions of the eclogite facies suggesting seismic slip in the deep crust [29,31]. Other fractures are filled with quartz and hydrous minerals. Static transformation of granulite into eclogite is observed in parallel bands along the fractures. Eclogitization is assisted by fluid influx in the fracture and stress-enhanced diffusion from the fracture toward the host granulite [55].

The main eclogite parageneses recrystallizing from the anorthosite is omphacite, garnet, kyanite, zoizite, phengite as well as rutile, quartz and amphibole, while more basic eclogites contain omphacite, garnet, phengite, rutile, quartz and carbonates [47]. Eclogitic minerals are found first inside localized fractures inside nonrecrystallized granulites as well as inside $\mathrm{dm}$-wide dark bands of partially recrystallized granulites on either sides of the fractures. Deformation then evolves in the form of narrow shear zones with a well-defined eclogite foliation cutting across the otherwise undeformed granulite. These shear zones then become thicker and longer, and form a continuous network surrounding rigid blocks of undeformed granulite of various sizes (from a few $\mathrm{dm}$ to several hundreds of meters). 


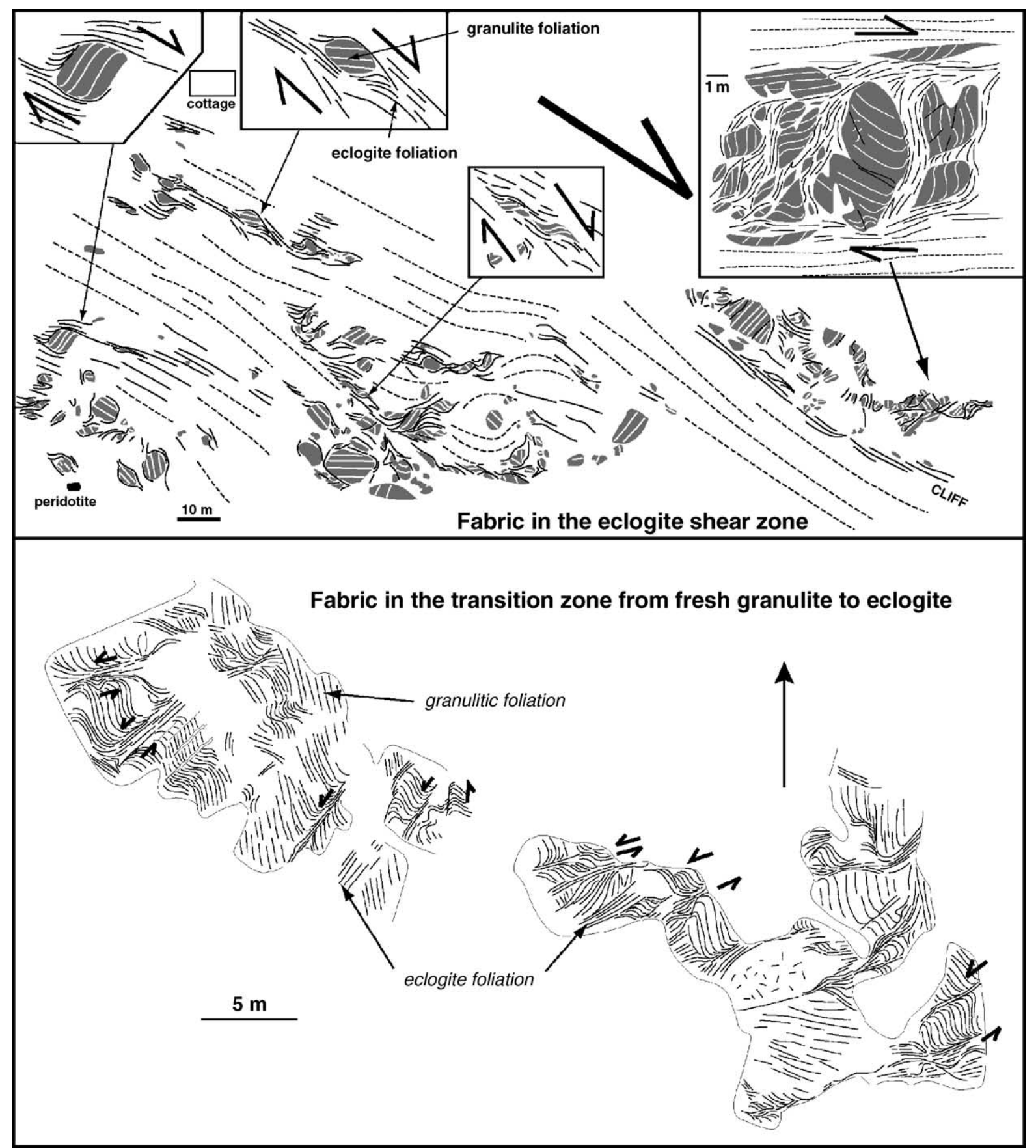

Fig. 3. Upper: detailed map of the eclogite foliation and granulite blocks near Seatrevik in Holsnøy. Inserts shows details of meter-scale top-tothe-east kinematic indicators. Lower: parralel shear zones, conjugate to the main dextral ones in the intermediate domain between the highly deformed and eclogitized region and the pristine granulite. 
It is important to note that eclogitization starts before any significant ductile deformation occurs. It is only once rocks have started to recrystallise with eclogite-facies mineral associations that ductile shear zones start to form. This shows that granulite is stronger than eclogite and can resist deformation in the P-T conditions of the eclogite facies. The transformed material is then deformed in a ductile manner and high strain shear zones form between granulite pods. Field relations show that increasing deformation is associated with increasing recrystallization of eclogite-facies parageneses. Between pristine granulite and highly transformed eclogite shear zones angular blocks of granulite are caught within an eclogite matrix ("eclogite breccia") and show large relative rotations. The angular shapes of the granulite blocks suggest that the interleaved eclogite shear zones in between were indeed derived from fractures. This example thus shows that large masses of granulites can persist metastable in the deep parts of the subduction channel until they are affected by seismic deformation and fluid income that will assist recrystallisation [30,31]. The average density of the metamorphic massif is thus lower than that of a fully recrystallised eclogite of mafic composition (3.5 [56]) and it is conceivable that buoyancy forces can be efficient in exhuming tectonic units from beyond the depth of formation of eclogites.

The significant volume reduction associated to eclogitization as well as the heterogeneous distribution of recrystallisation might induce stress concentration high enough to produce seismic deformation. The small amount of water present in the eclogite might also trigger the nucleation of earthquakes [57]. But the kinematic boundary conditions (whether the massif deforms by simple shear or pure shear for example) are not known. In the case of Holsnøy local observations [54] and reconnaissance work by two of us (TBA and HA) [58] have suggested that the deformation in the eclogite facies shear zones in Holsnøy involves topto-the-east shear zones. However, no systematic structural study has been undertaken so far to unravel the kinematic boundary conditions at peak pressure during the transformation of granulite to eclogite. We have thus used a simple approach (Fig. 3) which is to systematically map granulite boudins and eclogite foliation at the scale of several hundred meters from the little-transformed granulite toward an eclogite shear zone in the southern part of the area mapped by Boundy and Austrheim [47]. Given the size of heterogeneities (frequently the preserved granulite lenses reach several tens of meters) only a detailed map can show whether the fabric is symmetric or asymmetric and highlight the nature of the deformation at the bottom of the subduction channel.

\section{A detailed map in southern Holsnøy, mapping of the roots of subduction zones}

The studied area is located within a major eclogite shear zone as mapped by Austrheim and coll [47] next to a large preserved granulite massif. The eclogite show a distinct foliation and a quite consistent stretching lineation. The granulite blocks vary in size from a few tens of centimeters to several hundred meters or more. The Precambrian fabric in the granulite shows a foliation and a strong lineation, marked by the elongation of coronae. In the mapped area stretching is E-W to NE-SW and the eclogite foliation generally trends $\mathrm{N} 120^{\circ} \mathrm{E}$ but it is deflected around granulite lenses (Fig. 3). The eclogite foliation shows a sigmoidal geometry compatible with a dextral or top-to-the-east sense of shear. The granulitic foliation also shows sigmoids near the edges of resistant granulite lenses (Fig. 4). This observation can be made at the scale of the mapped area or at the scale of individual granulite lenses that behave as rigid inclusions in the non-coaxial flow (Fig. 3). Fig. 4a shows asymmetric granulite lenses caught in the eclogite foliation that displays a sigmoidal pattern compatible with top-to-the-east shear. This geometry is observed in the core of a $\mathrm{km}$-scale eclogite shear zone. The major shear zones trend NW-SE but conjugate shear zones trending NE-SW are observed in less-deformed regions. These conjugate shear zones show the opposite shear sense with a normal component with a top-to-the west displacement. Fig. $4 \mathrm{~b}$ and $\mathrm{c}$ show left-lateral shear zones highly oblique on the main shear zone in the zone of transition from the fresh granulite to the eclogite. Both sets of shear zones (major ones and their conjugates) show a clear pattern that dissects the fresh granulite into rhomboedric blocks arranged in a bookshelf fashion (Fig. 5). This geometry is typical of the region mapped by Austrheim and coworkers as "eclogite breccia" inter- 

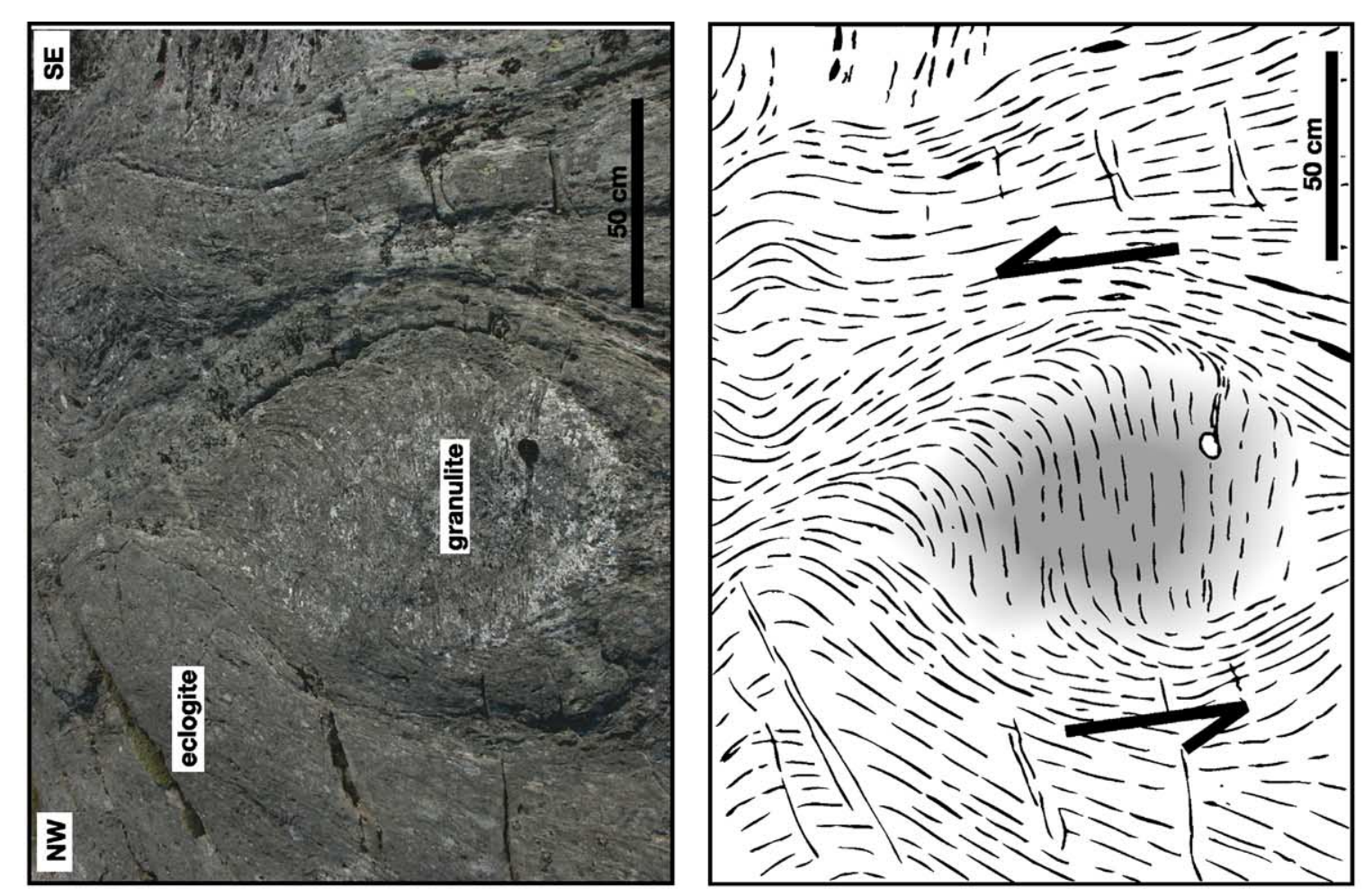

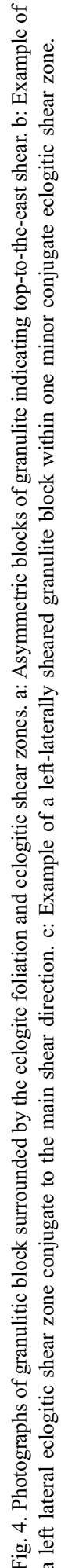
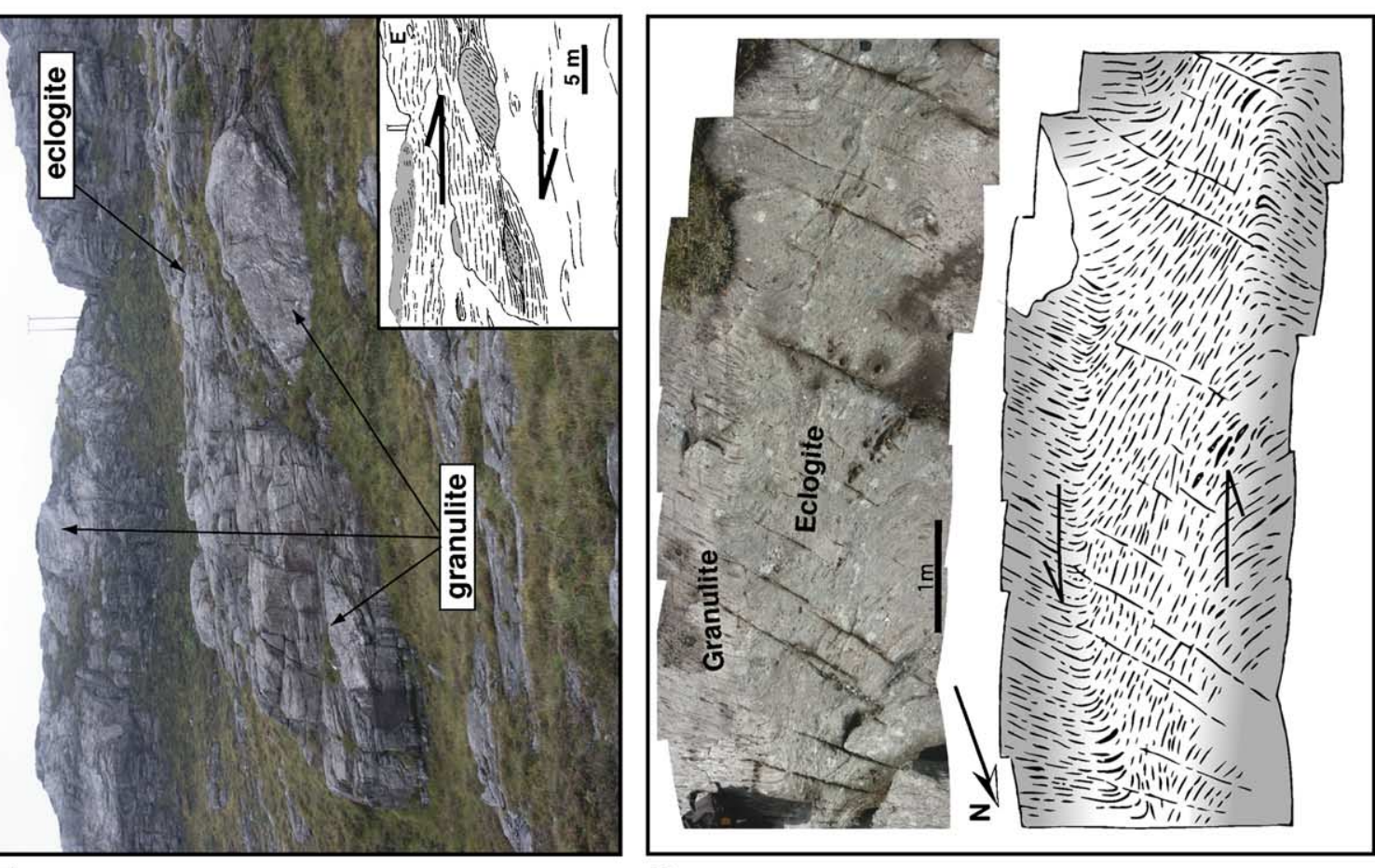

을 


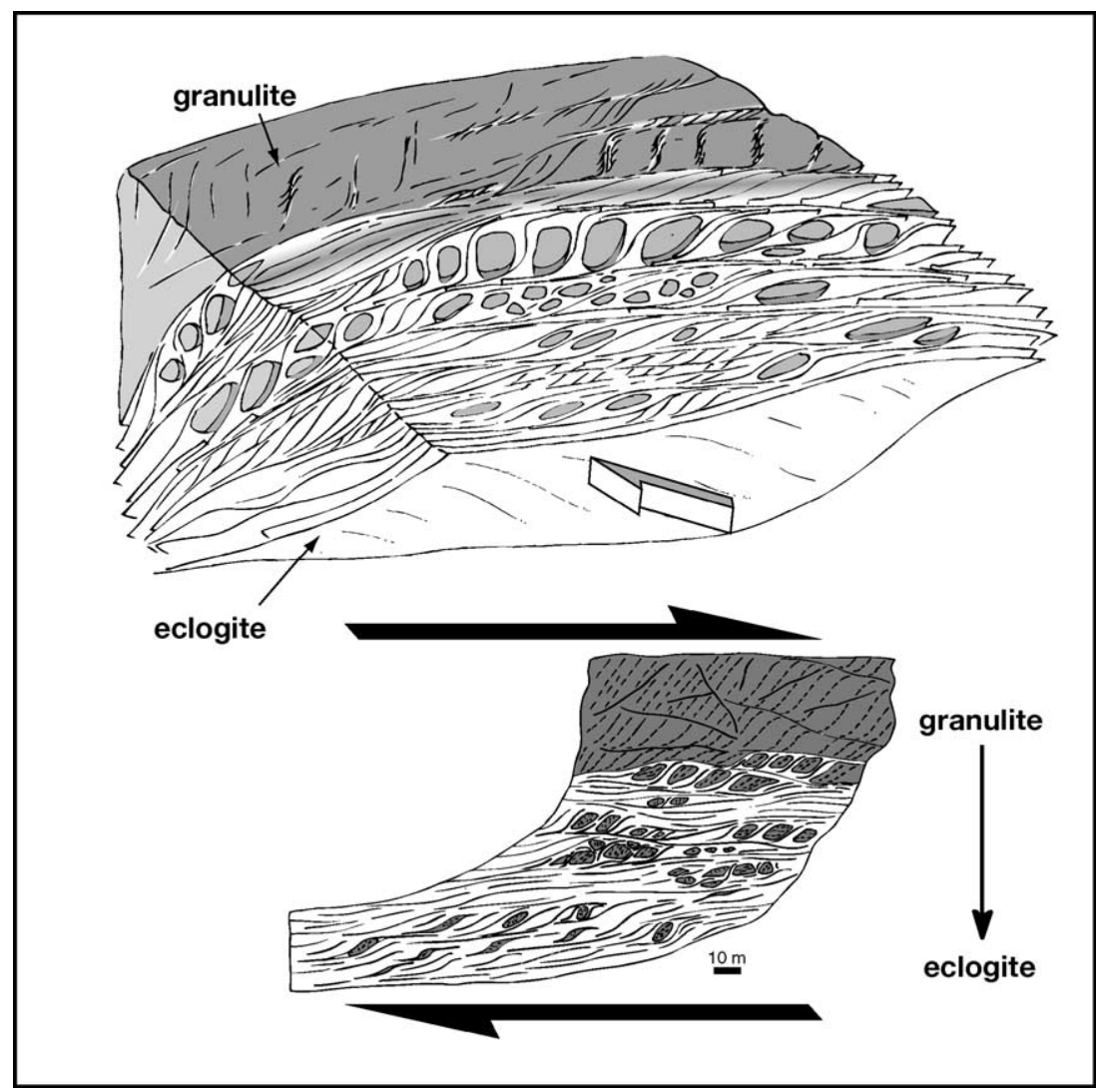

Fig. 5. Schematic interpretation of the progressive deformation of the Holsnøy granulite during top-to-the-east shear. Upper: 3D sketch of the transition from the fresh granulite (grey) to the eclogite shear zone (white) showing the dip of the lineation and the component of normal sense in the present geographic coordinates. Lower: Map view showing the relation between the intensity of shear and the amount of recrystallisation in the eclogite facies.

mediate between the intact granulite and the fully recrystallized eclogitic shear zones.

We can propose the following progressive history of deformation and eclogitization based on these observations (Fig. 5). During Caledonian subduction, within a top-to-the-east shear zone, metamorphic recrystallisation within the subducting crust is delayed until seismic brittle deformation allows fluid infiltration which in turn triggers eclogitization. Eclogitized fractures localizes ductile deformation with a bookshelf geometry, master top-east shear zones and minor conjugate ones. Further eclogitization is then favoured by further deformation and fluid infiltration. This results into the formation of isolated blocks of granulite that rotate within the overall ductile flow in the matrix depending on their initial orientation and aspect ratio. Once the blocks are separated from each other by the eclogitic matrix they will behave more or less as rigid inclusions within the shear zone and an asymmetric fabric will further develop.

A preliminary survey of the remaining part of Holsnøy island shows that (1) similar top-to-the-east shear criteria as well as the bookshelf geometry can be observed in other places although we did not undertake a precise mapping of the whole region, and (2) that top-to-the-east shear is also observed along amphibolite facies shear zones (Fig. 2) suggesting this deformation continued at lower pressure during exhumation. The top-east shear thus started at peak pressure in the eclogite facies and continued at lower pressure in the amphibolite facies. It was thus contemporaneous with exhumation. 
Furthermore, the map pattern of the shear zones described by Boundy and Austrheim [47] shows the same sigmoidal shape (Fig. 2) as the detailed map near Saetrevik suggesting that the whole tectonic unit was affected by the top-to-the-east shear on a plurikilometric scale.

These observations of a consistent kinematic pattern during eclogitization show that the boundary conditions involved a significant component of top-to-theeast non-coaxial flow and that the shear zones mapped by Austrheim et al. [47] probably accomodated a significant eastward displacement during eclogitization and later amphibolitization during exhumation. This deformation is older than the top-to-the-west shear along the basal shear zone of the Bergen Arcs that relates to the post-orogenic extensional stage $[33,59]$ and extends northward into the Kvamshesten and Nordfjord detachments zones in the Western Gneiss Region $[28,60]$.

\section{Conclusion and discussion}

Mapping of syn-eclogite deformation in the Lindås nappe shows that kinematic boundary conditions that existed during the recrystallisation in the eclogites facies involved a significant component of eastward non-coaxial flow. This shear sense is globally compatible with the polarity of subduction and nappe emplacement (top-to-the-east) (Fig. 1) during the Caledonian orogeny [59] and it is thus reasonable to postulate that it corresponds to shearing within the subduction channel. One more superficial equivalent of these deep shear zones would be the thrust at the base of the Bergen arc or the base of the Jotun Nappe before their reactivation as extensional shear zones during the post-orogenic stage. P-T conditions $\left(650-750{ }^{\circ} \mathrm{C}\right.$ and $\left.15-17 \mathrm{Kbar}[8,47]\right)$ suggest that this non-coaxial deformation has taken place at a depth of around $50 \mathrm{~km}$. An identical deformation regime seems to accompany the ascending eclogite in the amphibolite facies at lower pressure $\left(600-700{ }^{\circ} \mathrm{C}\right.$, 8-12 Kbar, [41,44]). The deformation recorded at peak pressure continued during exhumation with the same kinematics. Thus identified, the deformation associated with the eclogitization process is of particular interest: it corresponds to the first event that is associated with exhumation from the maximum depth. The question of a causal relation is thus raised. Is eclogitization responsible for exhumation?

A positive answer to this question might seem counter-intuitive because eclogitization leads to a density increase and should thus work against exhumation. In a general sense syn-orogenic exhumation requires positive buoyancy forces. This is well illustrated by the example of the Urals where extension has played a limited role in the exhumation of eclogites [61]. Leech [61] argues that complete eclogization ultimately leads to delamination of the crustal root that is definitely lost. Two remarks should be made at this stage: (1) exhumed units of the Bergen Arcs are not entirely eclogitized and their bulk density is thus intermediate between that of granulite and eclogites and, (2) it is quite possible that a significant amount of more strongly recrystallized units have been subducted in the mantle and never came back to the surface. We may furthermore argue that for a tectonic unit to start its way up within the subduction channel it must be decoupled from the descending lithosphere which requires the formation of shear zones to accommodate the relative displacement of the descending lithosphere and exhuming unit. These shear zones must form at the peak of pressure when that unit starts its journey back to the surface and continue to work at lower pressure during exhumation. That is exactly what is observed in the area we surveyed. Any process able to soften the rock locally will enhance the formation of shear zones. At such depths, before deformation is significant enough to reduce the grain size or produce enough shear heating to localize shearing deformation, fluid income in fractures and metamorphic reactions can potentially reduce the rock strength.

The recrystallisation of granulites into eclogites is associated with a significant drop in rock strength as shown by the preferential localisation of shear zones where recrystallisation has started. Although it may seem counter-intuitive eclogitization in that case will help the formation of large shear zones and thus favour the decoupling of portions of the crust from the subducting lithosphere. The drop in strength associated with eclogitization may allow initiation of exhumation. The first deformation that leads to a weakening of the granulitic basement and the formation of eclogitic shear zones can be correlated, kinematically and temporally, to the main Caledonian subduction, and to exhumation. The granulitic base- 
ment was left undeformed until it was affected by seismic deformation, fluid infiltration and recrystallisation, and this did not happen before the tectonic unit reached a depth of 40-60 km eclogitization.

This drop in strength is evidenced in the field by strain localisation that shows that eclogite is weaker than granulite. The few experimental studies devoted to the rheology of eclogites suggest that their strength is very similar to that of harzburgite and that the weak phase is omphacite [62]. Their experiments show that a garnetite is much stronger than the eclogite while an omphacitite is much weaker, further suggesting a partition of strain in the omphacite-rich layers. These results suggest that garnet is the highly resistant phase of the eclogites. Newly recrystallized garnets in the eclogite shear zones of the Bergen arcs are of small grain size and they do not form a continuous network, and thus they cannot contribute much to the overall resistance of the eclogites. Granulites are rich in large grain size garnets, feldpars and pyroxenes that may confer a higher resistance to the rocks. The presence of water can dramatically affect the strength of the various layers of the lithosphere [57,63], the presence of fluids in the eclogite and their total absence in the granulite might also explain the relative weakness of the eclogite. The occurrence of earthquakes in the lower crust of old cratons suggest a strong rheology for granulite [64] supposed to be stronger than the underlying mantle. More experimental studies devoted to the comparison of a dry granulite and a wet eclogite similar to those found in the Bergen Arcs are necessary to explain the observation that eclogite localize deformation while granulites remain rigid.

We propose a model of subduction and exhumation of continental units involving brittle deformation and the formation of ductile shear zones at the depth of the eclogite facies within the subduction channel (Figs. 6 and 7). The continental basement is dragged downward along with the subducting lithosphere. Despite their relatively low density, continental units follow

\section{1: fracturing}

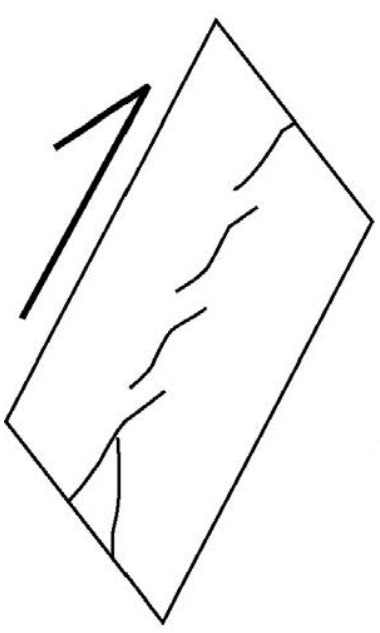

2: fluid infiltration and eclogitisation

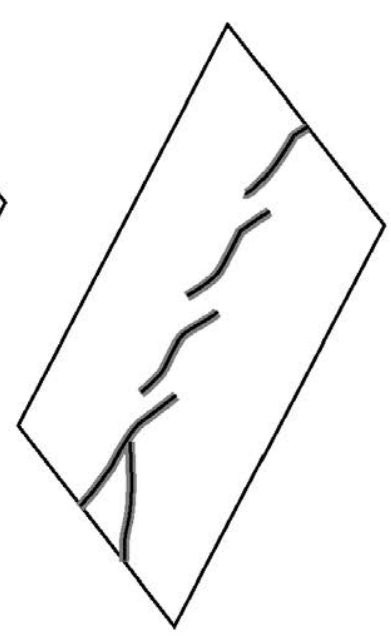

3: ductile deformation, further eclogitization, and connection of shear zones

\section{4: decoupling of units along eclogitic shear zones}
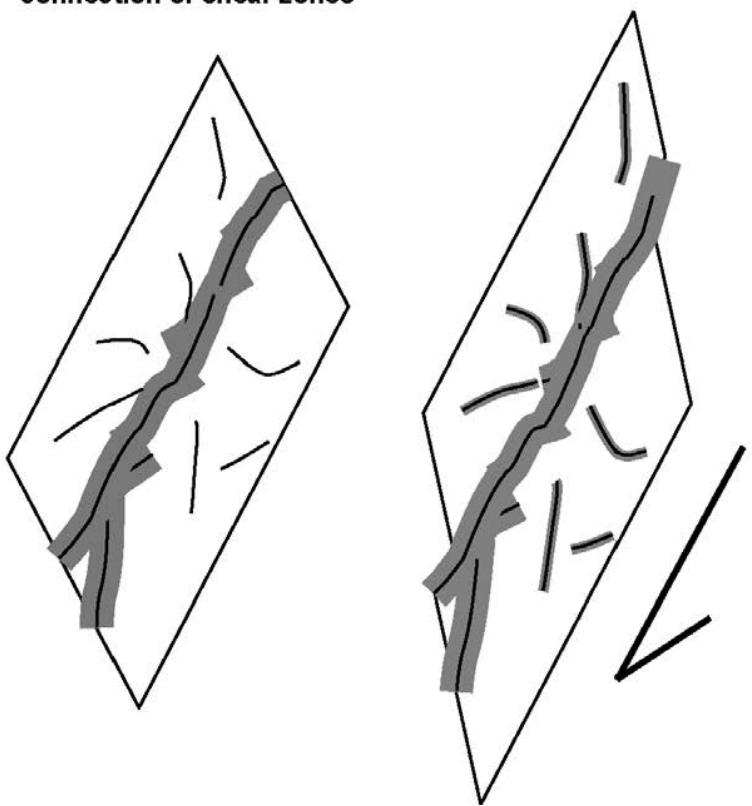

Fig. 6. Progressive formation of shear zones and eclogitization leading to the individualization of tectonic units. The first recorded deformation is the formation of fractures that allows for fluid infiltration and beginning of recrystallisation of eclogite -facies minerals. Eclogitization induces a drop of resistance and the localisation of ductile deformation and the formation of shear zones. Once these shear zones are connected to each other they form large-scale shear zones that allow the decoupling of rock masses from the subducting lithosphere. Because the granulite is not fully eclogitised it is still buoyant and the detached units start to exhume in the subduction channel. 


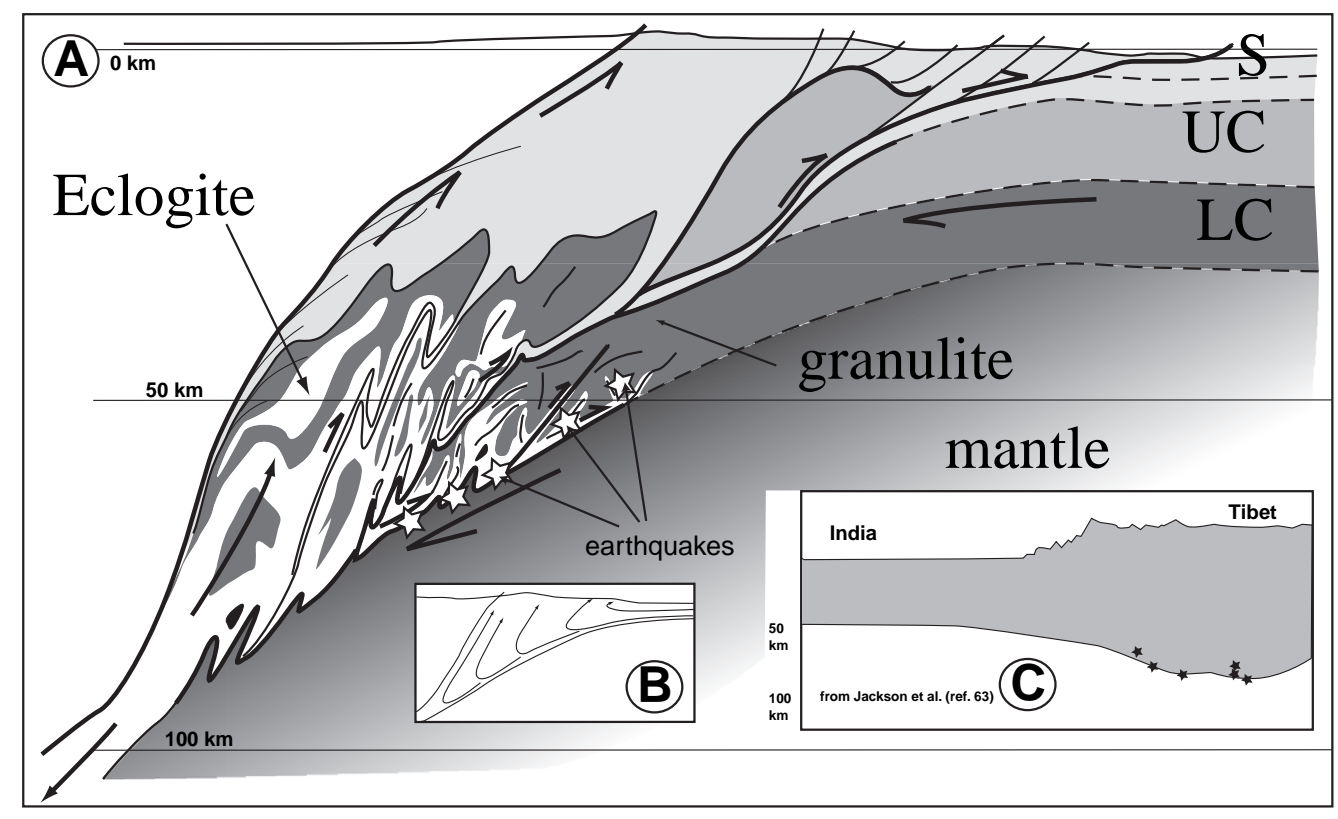

Fig. 7. A: Synthetic conceptual model of burial and exhumation during continental subduction. B: Schematic trajectories of particles within the subduction channel. C: Deep earthquakes below the Himalayas [63].

the descending lithosphere until buoyancy forces and forces due to shearing in the subduction channel overcome the strength of the crust/mantle boundary or any other rheological transition such as the brittle-ductile transition or the basement-cover interface.

Is it possible that some of the syn-eclogite deformation occurred also during burial? As said above the top-to-the-east shear occurred during the exhumation from the depth of eclogites to the depth of amphibolites. It is possible that some syn-eclogite deformation happened in the eclogite facies before the connection of large shear zones and thus before the decoupling of the exhumed tectonic units from the subducting lithosphere, thus during burial. But if this burial were important it would imply large pressure differences and this would show in the metamorphic parageneses. We thus do not think this possible burial during the syn-eclogite deformation was large.

Andersen et al. [7] and Brueckner and Medaris [65] have suggested that in the Western Gneiss Region mantle peridotites are included in the subducted continental crust by shearing deformation along the walls of the subduction channel. In the case of the Himalayas clustering of deep seismic events near the Moho [63] may suggests the formation of a shear zone along this rheological discontinuity that is likely to localise shearing deformation [66]. The inclusion of peridotite lenses within the eclogitized granulites of the Bergen Arc and of the Western Gneiss Region could be explained by shearing deformation along the Moho during subduction.

The first interfaces to be activated as shear zones are the weakest ones, usually the shallowest, such as the basement-cover boundary. Basement units are subjected to shearing but do not deform significantly in the first $40-50 \mathrm{~km}$ until they are fractured and invaded by fluids. Shear zones then localize and propagate together with eclogitization. Once the shear zones have been connected to each other a piece of the subducting basement will be decoupled from the rest of the subducting lithosphere. This rock slice will no longer be subjected to the pull force exerted by the suducting slab and, because it is not entirely eclogitized and still buoyant, will start its ascent toward the surface.

This mechanism is very similar to the formation of a deep accretionary complex where those units below the decollement are subducted and those above are not. Tectonic units are subducted until they are decoupled from the subducting lithosphere by the 
propagation of a decollement from within the sedimentary section to the basement-cover interface, then to the brittle-ductile transition and then to the Moho. In the case of the Bergen Arcs eclogites the propagation of the decollement involves fracturation and fluid infiltration, then weakening by recrystallisation in the eclogite facies of the deforming zones and strain localisation.

This implies that resistant lithologies should subduct deeper than weaker lithologies. This is true in general as most ultra-high pressure findings correspond to basement units $[1,2,4,67]$. The fact that the lower crust is rarely present in accreted units also corroborates this point of view: in the Alps for instance lower crustal units are absent $[68,69]$ except for the Ivrea zone that was exhumed early during the Mesozoic rifting episode [70]. In the Eastern Mediterranean region the Hellenides do not show any lower crustal material and most of the chain is made of accreted sedimentary units derived from the Apulian platform [18]. Basement units are however found laterally to the west in the Menderes massif (western Turkey) and probably underlie part of the Aegean domain showing that the basement behaves independently from the overlying cover [71]. The recent finding of UHP parageneses in basement units of the Rhodope [72] north of the Hellenides further confirms this rule. This view is not entirely true however: The rare occurrence of ultra-high-pressure parageneses in metasediments such as metacherts in the Alps [73] suggest that sediments can reach the deepest zones of the subduction channel either during oceanic subduction because they are more strongly attached to the oceanic crust than overlying turbidites or during subsequent continental subduction protected between more resistant basement units. Even in this case a recent study [74] shows that the rate of burial of the Lago di Cignana UHP unit is compatible with the estimated rate of convergence suggesting that these metasediments reached the stability field of coesite at the same velocity as the subducting oceanic slab, implying that they were still attached to it until large depths.

Our model is significantly different from Chemenda's [23] who suggests that the whole crust (or upper crust at least) is decoupled from the subducting slab and exhumed by buoyancy forces. Most mountain belts show independent units (nappes) much thinner than the crust. But the general mechanism can be kept and our observations might be a real case observation of this process. Our model suggests that depending upon their initial strength, tectonic units will reach various depths during subduction, the strongest being buried deeper in general and thus smaller units will form until the decollement is deep enough to mobilise thicker units.

Our observations also suggests that deformation at depth within the subduction channel is controlled by far-field stresses compatible with subduction of a rigid lid of lithosphere because the kinematics of underthrusting and tectonic accretion is similar from the surface (emplacement of nappes onto the foreland) down to the depth of eclogites. The fact that the deformation is still localized at depth along weak shear zones rich in fluids and compatible with the sense of shear imposed by subduction further confirm that mountain belts are formed by continental subduction and not by a simple buckling of the lithosphere or the crust as suggested in recent models [75].

The counter-intuitive view that eclogitization, despite density increase, may trigger exhumation because of the associated drop in rock strength requires that eclogitization is not complete, and especially in basic and intermediate lithologies that may become denser than the mantle if eclogitization in case of complete recrystallization. It also requires that eclogitization leads to a resistance drop due, for instance, to the presence of fluids. The Bergen Arcs provide an example of such behaviour in a continental subduction regime. Is this behaviour possible in oceanic subduction? Oceanic gabbros may possibly behave in the same way during eclogitization. The examples of the Monviso eclogites in the FrenchItalian Alps [76] or of Alpine Corsica where large parts of the exhumed bodies are left undeformed and between eclogitic and blueschists shear zones [77-79] may represent oceanic equivalents. Totally recrystallized eclogites are usually of small size and were often embedded in lighter material such as serpentinite or metasediments that favoured their exhumation. It is very likely that the exhumation of large scale totally recrystallized eclogites of intermediate to basic composition is impossible and our model is not incompatible with the traditional view that eclogitization in general works against exhumation. 


\section{Acknowledgments}

Special thanks are due to Mary Leech and anonymous reviewers who provided useful and constructive comments on an earlier version of this manuscript. This is a contribution of the Laboratoire de Tectonique UMR 7072, funded by INSU-IT.

\section{References}

[1] C. Chopin, Coesite and pure pyrope in high-grade blueschists of the western Alps: a first record and some consequences, Contrib. Mineral. Petrol. 86 (1984) 107-118.

[2] D.C. Smith, Coesite in clinopyroxene in the caledonides and its implications for geodynamics, Nature 310 (1984) 641-644.

[3] S. Maruyama, J.G. Liou, M. Terabayashi, Blueschists and eclogites of the world and their exhumation, Int. Geol. Rev. 38 (6) (1996) 485-594.

[4] W.G. Ernst, J.G. Liou, Overview of UHP metamorphism and tectonics in well-studied collisional orogens, in: W.G. Ernst, J.G. Liou (Eds.), Ultra-High Pressure Metamorphism and Geodynamics in Collision-Type Orogenic Belts, Geol. Soc. Amer., Boulder, Co., 2000, pp. 3-19.

[5] H. Austrheim, M. Erambert, A.K. Engvik, Processing of crust in the root of the Caledonian continental collision zone: the role of eclogitization, Tectonophysics 273 (1997) 129-154.

[6] H. Austrheim, Eclogitization of lower crustal granulites by fluid migration through shear zones, Earth Planet. Sci. Lett. 81 (1987) 221-232.

[7] T.B. Andersen, B. Jamtveit, J.F. Dewey, E. Swensson, Subduction and eduction of continental crust: major mechanisms during continent-continent collision ans orogenic extensional collapse, a model based on the south Norwegian Caledonides, Terra Nova 3 (1991) 303-310.

[8] H. Austrheim, W.L. Griffin, Shear deformation and eclogite formation within granulite-facies anorthosites of the Bergen Arcs, Western Norway, Chem. Geol. 50 (1985) $267-281$.

[9] T. Igarashi, T. Matsuzawa, N. Umino, A. Hasegawa, Spatial distribution of focal mechanisms for interplate and intraplate earthquakes associated with the subducting Pacific plate beneath the northeastern Japan arc: a triple planed deep seismic zone, J. Geophys. Res. 106 (B2) (2001) 2177-2191.

[10] R.D. Hyndman, K. Wang, M. Yamano, Thermal constraints on the seimogenic portion of the southwestern Japan subduction thrust, J. Geophys. Res. 100 (B8) (1995) 15373-15392.

[11] W. Jiao, P.G. Silver, Y. Fei, C.T. Prewitt, Do intermediate and deep-focus earthquakes occur on preexisting weak zones. An examination of the Tonga subduction zone, J. Geophys. Res. 105 (B12) (2000) 28125-28138.

[12] S.H. Kirby, S. Stein, E.A. Okal, D.C. Rubie, Metastable mantle phase transformations and deep earthquakes in subducting oceanic lithosphere, Rev. Geophys. 34 (2) (1996) 261-306.
[13] B.R. Hacker, S.M. Peacock, G.A. Abers, S.D. Holloway, Suduction factory 2 . Are intermediate earthquakes in subducting slabs linked to metamorphic dehydration reactions? J. Geophys. Res. 108 (B1) (2003) 2030, doi:10.1029/2001JB00129.

[14] S. Kirby, E.R. Engdahl, R. Delinger, Intermediate-depth intraslab earthquakes and arc volcanism as physical expression of crustal and upper mantle metamorphism in subducting slabs (overview), in: I. Bebout, E. Gray (Eds.), Subduction, Top to Bottom, Geophysical Monograph, vol. 96, American Geophysical Union, Washington, 1996, pp. 195-214.

[15] T. Seno, Y. Yamanaka, Double seismic zones, compressional deep trench — outer rise events, and superplumes, in: I. Bebout, E. Gray (Eds.), Subduction, Top to Bottom, vol. 96, American Geophysical Union, Washington, 1996, pp. 347-355.

[16] T. Seno, T. Yamasaki, Low-frequency tremor, intraslab and interplate earthquakes in southwest Japan - from a viewpoint of slab dehydration, Geophys. Res. Lett. 30 (22) (2003) 2171, doi:10.1029/2003GL018349.

[17] B.R. Hacker, Eclogite formation and the rheology, buoyancy, seismicity, and $\mathrm{H} 2 \mathrm{O}$ content of oceanic crust, in: I. Bebout, E. Gray (Eds.), Subduction, Top to Bottom, Geophysical Monograph, vol. 96, American Geophysical Union, Washington, 1996, pp. 337-346.

[18] L. Jolivet, C. Faccenna, B. Goffé, E. Burov, P. Agard, Subduction tectonics and exhumation of high-pressure metamorphic rocks in the Mediterranean orogens, Am. J. Sci. 303 (2003) 353-409.

[19] J.P. Platt, Exhumation of high-pressure rocks: a review of concept and processes, Terra Nova 5 (1993) 119-133.

[20] U. Ring, M.T. Brandon, S.D. Willett, G.S. Lister, Exhumation processes, in: U. Ring, M.T. Brandon, S.D. Willett, G.S. Lister (Eds.), Exhumation Processes: Normal Faulting, Ductile Flow and Erosion, Special Publication, vol. 154, Geological Society, London, 1999, pp. 1-27.

[21] E. Burov, L. Jolivet, L. Le Lepourhiet, A. Poliakov, A thermomechanical model of exhumation of HP and UHP metamorphic rocks in Alpine mountain belts, Tectonophysics 342 (2001) 113-136.

[22] T.V. Gerya, B. Stöckert, A.L. Perchuk, Exhumation of highpressure metamorphic rocks in a subduction channel: a numerical simulation, Tectonics 21 (6) (2002) 1056, doi:10.1029/ 2002 TC001406.

[23] A.I. Chemenda, M. Mattauer, J. Malavieille, A.N. Bokun, A mechanism for syn-collision rock exhumation and associated normal faulting: results from physical modelling, Earth Planet. Sci. Lett. 132 (1995) 225-232.

[24] S. Guillot, K.H. Hattori, J. de Sigoyer, Mantle wedge serpentinization and exhumation of eclogites, insights from eastern Ladakh, northwest Himalaya, Geology 28 (2000) 199-202.

[25] L. Labrousse, L. Jolivet, P. Agard, R. Hébert, T.B. Andersen, Crustal-scale boudinage and migmatization of gneiss during their exhumation in the UHP province of western Norway, Terra Nova 14 (2002) 263-270.

[26] C. Henry, A. Michard, C. Chopin, Geometry and structural evolution of ultra-high pressure and high pressure rocks from the Dora Maira massif, Western Alps, J. Struct. Geol. 15 (1993) 965-981. 
[27] A. Wain, New evidence for coesite in eclogite and gneiss: defining an ultrahigh-pressure province in the western Gneiss region of Norway, Geology 25 (1997) 927-930.

[28] M. Krabbendam, A. Wain, Late-Caledonian structures, differential retrogression and structural position of (ultra)high-pressure rocks in the Nordfjord-Stadlandet area, western Gneiss region, NGU Bull. 432 (1997) 127-139.

[29] H. Austrheim, T. Boundy, Pseudotachylites generated during seismic faulting and eclogitization of the deep crust, Science 265 (1994) 82-83.

[30] A.K. Engvik, H. Austrheim, T.B. Andersen, Structural, mineralogical and petrophysical effects on deep crustal rocks of fluid-limited polymetamorphism, western Gneiss Region, J. Geol. Soc. (Lond.) 157 (2000) 121-134.

[31] M.G. Bjørnerud, H. Austrheim, M.G. Lund, Processes leading to eclogitization (densification) of sibducted and tectonically buried crust, J. Geophys. Res. 107 (B10) (2002), doi:10.1029/ 2001JB000527.

[32] T.B. Andersen, P.T. Osmundsen, L. Jolivet, Deep crustal fabric and a model for the extensional collapse of the southwest Norwegian Caledonides, J. Struct. Geol. 16 (9) (1994) $1191-1203$.

[33] H. Fossen, Extensional tectonics in the Caledonides: synorogenic or postorogenic? Tectonics 19 (2) (2000) 213-224.

[34] D. Roberts, D.G. Gee, An introduction to the structure of the Scandinavian Caledonides, in: D.G. Gee, B.A. Sturt (Eds.), The Caledonide Orogen: Scandinavia and Related Areas, J. Wiley, Chichester, 1985.

[35] T.H. Torsvik, M.A. Smethurst, J.G. Meert, R. van der Voo, W.S. McKerrow, M.D. Brasier, B.A. Sturt, H.J. Walderhaug, Continental break-up and collision in the Neoproterozoic and Palaeozoic - a tale of Baltica and Laurentia, Earth Sci. Rev. 40 (1996) 229-258.

[36] M.P. Terry, P. Robinson, M. Hamilton, M.J. Jercinovic, Monazite geochronology of UHP and HP metamorphism, deformation and exhumation, Nordoyane; western Gneiss region, Norway, Am. Mineral. 85 (2000) 1651-1664.

[37] L. Labrousse, L. Jolivet, T.B. Andersen, P. Agard, R. Hû̀bert, H. Maluski, U. ShûÂrer, Pressure-Temperature-Time-Deformation history of the exhumation of Ultra-High Pressure rocks in the Western Gneiss Region, Norway, in: D.L. Whitney, C. Teyssier, C.S. Siddoway (Eds.), Gneiss Domes in Orogeny, Geological Society of America Special Paper 380, Geological Society of America, Boulder, Colorado, 2004, pp. 155-183.

[38] L.F. Dobrzhinetskaya, E.A. Eide, R.B. Larsen, B.A. Sturt, R.G. Tronnes, D.C. Smith, W.R. Taylor, T.V. Posukova, Microdiamond in high-grade metamorphic rocks of the western Gneiss Region, Norway, Geology 23 (1995) 597-600.

[39] J.F. Dewey, P.D. Ryan, T.B. Andersen, Orogenic uplift and collapse, crustal thickness, fabrics and metamorphic phase changes: the role of eclogites, in: H.M. Prichard, T. Alabaster, N.B.W. Harris, C.R. Neary (Eds.), Magmatic Processes and Plate Tectonics, Geological Society Special Publication, vol. 76, 1993, pp. 325-343.

[40] A. Kühn, The influence of fluid on the granulite to eclogite and amphibolite facies transition: a study in the anorthositic rocks from the Lindås Nappe, Bergen Arcs, West Norway, $\mathrm{PhD}$ Thesis, University of Oslo, 2002.

[41] A. Kühn, J. Glodny, H. Austrheim, A. Råheim, The Caledonian tectonometamorphic evolution of the Lindås Nappe: Constraints from $\mathrm{U}-\mathrm{Pb}, \mathrm{Sm}-\mathrm{Nd}$ and $\mathrm{Rb}-\mathrm{Sr}$ ages of granitoid dykes, Norsk Geologisk Tidsskrift, in press.

[42] B. Bingen, H. Austrheim, M.J. Whitehouse, W.J. Davis, Trace element signature and $\mathrm{U} / \mathrm{Pb}$ geochronology of eclogite-facies zircon, Bergen Arcs, Caledonides of W Norway, Contrib. Mineral. Petrol. 147 (6) (2004) 671-683.

[43] C.F. Kolderup, N.H. Kolderup, Geology of the Bergen Arc System, 1940, $137 \mathrm{pp}$.

[44] T.M. Boundy, E.J. Essene, Rapid exhumation of lower crust during continent-continent collision and late extension: evidence from $40 \mathrm{Ar} / 39 \mathrm{Ar}$ incremental heating of hornblendes and muscovites, Caledonian orogen, western Norway, Geol. Soc. Amer. Bull. 108 (9) (1996) 1425-1437.

[45] R. Schmid, U. Altenberger, R. Oberhänsli, Polyphase tectonometamorphic evolution of the northwestern Lindås Nappe on Holsnøy, Bergen arcs, Caledonides, SW-Norway, Zbl. Geol. Paläont 1-2 (1999) 1-18.

[46] H. Austrheim, Eclogitization of the deep crust in continent collision zones, C. R. Acad. Sci. Paris 319 (1994) 761-774.

[47] T.M. Boundy, D.M. Fountain, H. Austrheim, Structural development and petrofabrics of eclogite facies shear zones, Bergen arcs, western Norway: implications for deep crustal deformation processes, J. Metamorph. Geol. 10 (1992) 127-146.

[48] B. Jamtveit, K. Bucher-Nurminen, H. Austrheim, Fluid controlled eclogitization of granulites in deep crustal shear zones, Bergen arcs, Western Norway, Contrib. Mineral. Petrol. 104 (2) (1990) 184-193.

[49] E.M. Klaper, Reaction-enhanced formation of eclogite-facies shear zones in granulite-facies anorthosites, in: R.J. Knipe, E.H. Rutter (Eds.), Deformation Mechanisms, Rheology and Tectonics, Geol. Soc. Spec. Pub., London, vol. 54, 1990, pp. $167-173$.

[50] K.M. Rockow, L.A. Haskin, B.K. Jolliff, D.M. Fountain, Constraint on element mobility associated with the conversion of granulite to eclogite along fractures in an anorthositic complex on Holsnoy, Norway, J. Metamorph. Geol. 15 (1997) 401-418.

[51] D. Mattey, D.H. Jackson, N.B.W. Harris, S. Kelley, Isotopic constraints on fluid infiltration from an eclogite facies shear zone, Holsenoy, Norway, J. Metamorph. Geol. 12 (1994) $311-325$.

[52] M. Krabbendam, A. Wain, T.B. Andersen, Pre-Caledonian granulite and gabbro enclaves in the western Gneiss Region, Norway: indications of incomplete transition at high pressure, Geol. Mag. 137 (3) (2000) 235-255.

[53] B. Bingen, W.J. Davis, H. Austrheim, Zircon U-Pb geochronology in the Bergen arc eclogites and their Proterozoic protoliths, and implications for the pre-Scandian evolution of the Caledonides in western Norway, GSA Bull. 113 (5) (2001) 640-649.

[54] P. Rey, D.M. Fountain, T.M. Boundy, Kinematic indicators in eclogite-facies rocks, in: A.W. Snoke, J. Tullis, V.R. Todd (Eds.), Fault-related rocks, A Photographic Atlas, pp. 444-447, Princeton University Press, Princeton, New Jersey, 1998. 
[55] B. Jamtveit, H. Austrheim, A. Malthe-Sørenssen, Accelerated hydration of the Earth's deep crust induced by stress perturbations, Nature 408 (2000) 75-78.

[56] B. Goffé, R. Bousquet, P. Henry, X. Le Pichon, Effect of the chemical composition of the crust on the metamorphic evolution of orogenic wedges, J. Metamorph. Geol. 21 (2003) $123-141$.

[57] J. Zhang, H.W. Green Jr., K. Bozhilov, Z. Jin, Faulting induced by precipitation of water at grain boundaries in hot subducting oceanic crust, Nature 428 (2004) 633-636.

[58] T.B. Andersen, H. Austrheim, Pre-Symposium Excursion Guide: Bergen-Selje, Norway Eclogite, 2003, 70 pp.

[59] H. Fossen, The role of extensional tectonics in the Caledonides of south Norway, J. Struct. Geol. 14 (1992) 1033-1046.

[60] T.B. Andersen, Extensional tectonics in the Caledonides of southern Norway, an overview, Tectonophysics 285 (3-4) (1998) 333-352.

[61] M.L. Leech, Arrested orogenic development: eclogitization, delamination, and tectonic collapse, Earth Planet. Sci. Lett. 185 (2001) 149-459.

[62] Z.M. Jin, J. Zhang, H.W. Green Jr., S. Jin, Eclogite rheology: implications for subducted lithosphere, Geology 29 (8) (2001) $667-670$.

[63] J. Jackson, Strength of the continental lithosphere: time to abandon the jelly sandwich? GSA Today (2002 September) $4-10$.

[64] A. Maggi, J.A. Jackson, D. McKenzie, K. Priestley, Earthquake focal depths, effective elastic thickness, and the strength of the continental lithosphere, Geology 28 (6) (2000) 495-498.

[65] H.K. Brueckner, L.G. Medaris, A general model for the intrusion and evolution of "mantle" peridotites in high-pressure and ultra-high-pressure metamorphic terranes, J. Metamorph. Geol. 18 (2000) 123-133.

[66] M.R. Handy, J.P. Brun, Seismicity, structure and strength of the continental lithosphere, Earth Planet. Sci. Lett. 223 (2004) $427-441$.

[67] C. Chopin, H.P. Schertl, The UHP unit in the Dora-Maira massif, western Alps, Int. Geol. Rev. 41 (1999) 765-780.

[68] H. Laubscher, The problem of the Moho in the Alps, Tectonophysics 182 (1990) 9-21.

[69] X. Le Pichon, F. Bergerat, M.J. Roulet, Plate kinematics and tectonics leading to the Alpine belt formation, Geol. Soc. Am. Spec. Pap. 218 (1988) 111-131.

[70] M.R. Handy, L. Franz, F. Heller, B. Janott, R. Zurbriggen, Multistage accretion and exhumation of the continental crust (Ivrea crustal section, Italy and Switzerland), Tectonics 18 (6) (1999) 1154-1177.

[71] L. Jolivet, G. Rimmelé, R. Oberhänsli, B. Goffé, O. Candan, Correlation of syn-orogenic tectonic and metamorphic events in the Cyclades, the Lycian Nappes and the Menderes massif, geodynamic implications, Bull. Geol. Soc. France 175 (3) (2004) 217-238.

[72] E.D. Mposkos, D.K. Kostopoulos, Diamond, former coesite and supersilicic garnet in metasedimentary rocks from the Greek Rhodope: a new ultrahigh-pressure metamorphic province established, Earth Planet. Sci. Lett. 192 (2001) 497-506.

[73] T. Reinecke, Very-high pressure metamorphism and uplift of coesite-bearing metasediments from the Zermatt-Saas zone, Western Alps, Eur. J. Mineral. 3 (1991) 7-17.

[74] T.S. Lapen, C.M. Johnson, L.P. Baumgartner, N.J. Mahlen, B.L. Beard, J.F. Amato, Burial rates during prograde metamorphism of an ultra-high-pressure terrane: an example from Lago di Cignana, western Alps Italy, Earth Planet. Sci. Lett. 215 (2003) 57-72.

[75] K. Petrini, Y. Podladchikov, Lithospheric pressure-depth relationship in compressive regions of thickened crust, J. Metamorph. Geol. 18 (1) (2000) 67-78.

[76] P. Philippot, J.R. Kienast, Chemical-microstructural changes in eclogite-facies shear zones (Monviso, Western Alps, north Italy) as indicators of strain history and the mechanism and scale of mass transfer, Lithos 23 (3) (1989) 179-200.

[77] J.C. Lahondére, D. Lahondére, Organisation structurale des schistes lustrés du Cap Corse, C.R.A.S. 307 (1988) 1081-1086.

[78] M. Fournier, L. Jolivet, B. Goffé, R. Dubois, The alpine Corsica metamorphic core complex, Tectonics 10 (1991) $1173-1186$.

[79] H. Austrheim, T.B. Andersen, Pseudotachylites from Corsica: fossil earthquakes from a subduction complex, Terra Nova 16 (2004) 193-197.

[80] D.A. Carswell, S. Cuthbert, E. Krogh Ravna, Ultrahigh-pressure metamorphism in the western Gneiss Region of the Norwegian Caledonides, in: W.G. Ernst, J.G. Liou (Eds.), Ultrahigh-Pressure Metamorphism and Geodynamics in Collision-Type Orogenic Belts, Geological Society of America, 2000, pp. 149-159.

[81] P.T. Osmundsen, T.B. Andersen, The middle Devonian basins of western Norway: sedimentary response to large-scale transtensional tectonics? Tectonophysics 332 (2001) 51-68.

[82] W.J. Wilks, S.J. Cuthbert, The evolution of the Hornelen Basin detachment system, western Norway: implications for the style of late orogenic extension in the southern Scandinavian Caledonides, Tectonophysics 238 (1994) 1-30.

[83] B.R. Hacker, T.B. Andersen, D.B. Root, L. Mehl, J.M. Mattinson, J.L. Wooden, Exhumation of high-pressure rocks beneath the Solund Basin, Western Gneiss Region of Norway, J. Metamorph. Geol. 21 (2003) 613-629.

[84] E.S. Kildal, Geologisk kart over Norge, berggrunnskart. Måløy, 1:250 000, norsk utgave, N.G. Undersøkelse, ed., 1970.

[85] J. Ragnhildsveit, D. Helliksen, Geologisk kart over Norge, berggrunnskart. Bergen, 1:250 000, N.G. Undersøkelse, ed., 1997. 